\title{
The Development of Producer-Driven Commodity Chains in the Automobile Industry in Korea: Relations to Japan and the United States*
}

\author{
EUN MeE Kim
}

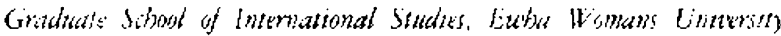

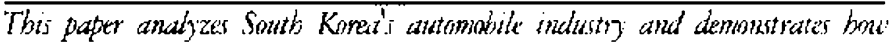
a semi-jeriphery ian sucressfully develop an autmobile inclustn withous its men basi of advanied technology or large actomitation of capital. By witlizing the

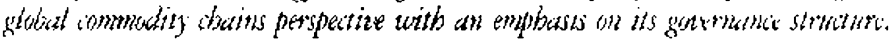

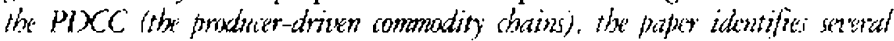

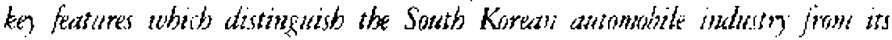

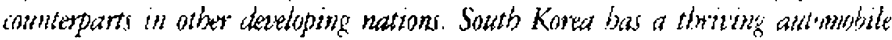

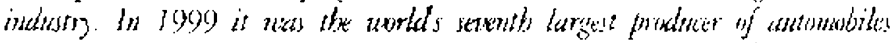

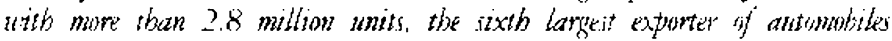

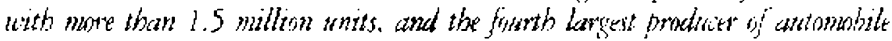

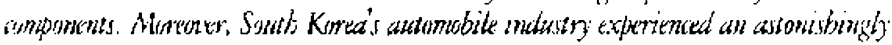
rapid grouth rate with an annual axtage growth rate of 26.7 percent betuken 1962-98. Soub Korva's automabile industry is also noterevoting in that it bai

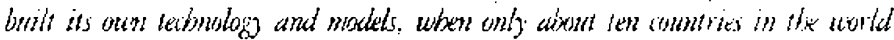

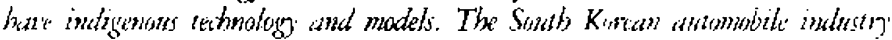

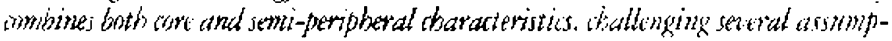
tions about a PDCC from the World System persputine and the commodity.

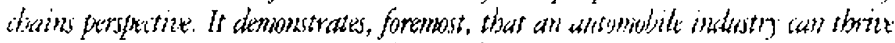

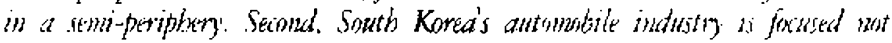

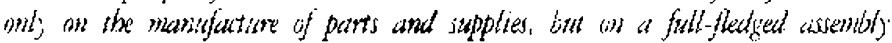

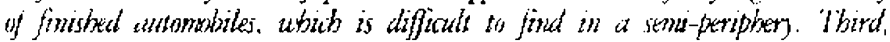

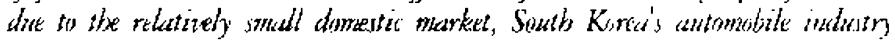

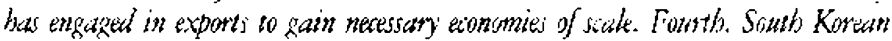

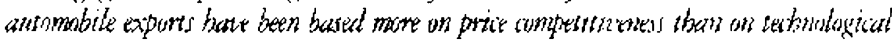

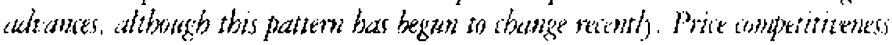

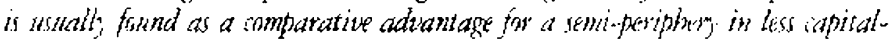

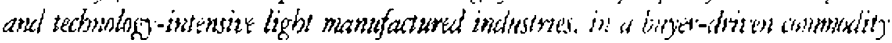

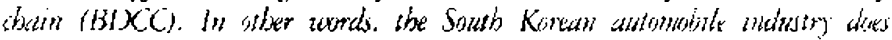

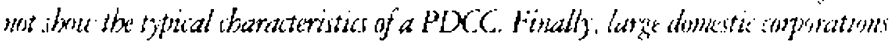

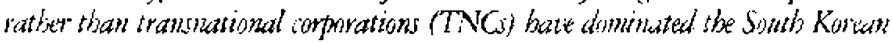

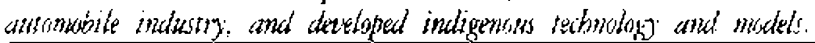

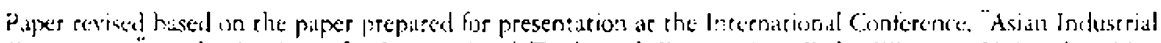

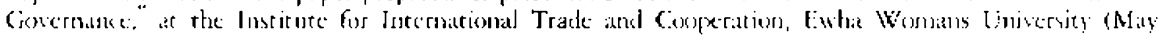
1. live! Rescarch was funded by a rescatch grant from the Astal Re'searcil fund. Ihe authur gratefully'

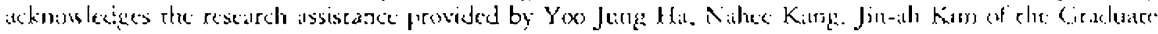

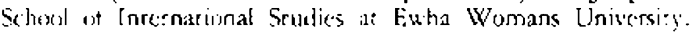

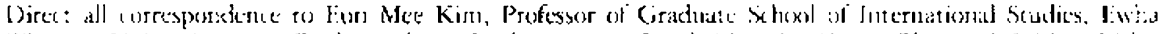

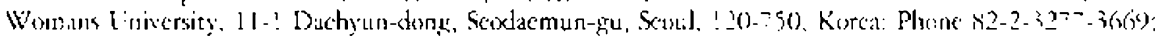

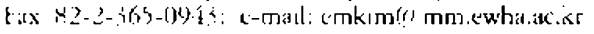




\section{INTRODUCTION}

The automobile industry is regarded as a vital induscry for a nation's comomic 1 development and industrial upgrading, since it provides numerous significant backward and forward linkages. However, it is nor an industry found in all nations. According to the World System perspective, the automobile industry is an industry exclusive to corc nations due to its capital-and technology-intensive nature. As a prime example of a producer-driven commodity chain (PDCC), it derives profits based on. "scale, volume. and cechnological advances," where the transnational corparations ( $\Gamma$ i C S ) play a pivural role (Gereffi 1994, 99).

However, South Korea, a semi-periphery nation, has a thriving automobile industry. In 1999 it was the world's seventh largest proxlucer of aucomobiles with more than 2.8 million units, the sixth largest exporter of automobiles with more than 1.5 million units, and the fourth largest producer of automobile components (Biggart and Guillen 199); Korea Automobile Manufacturers Association 200(1). I Moreover, Suuth Korea's automobile industry exporienced an astonishingly rapid yrowth rate with an annual average growth rate of 26.7 percent between 1962-98 (Korea Automobilc Manutacturers Association 1999). South Korea's automobile industry is also noteworthy in that it has built its own technology and models, when only about encouncries in the world have indigenous technology and models.

The South Korean automobile industry cumbines both cote and semi-peripheral characteristics, challenging several assumptions about a PDCC from the World System perspective and the commodity chains perspective. It demonstrates, foremost, that an autonobile industry can thrive in a semi-periphery. Second, South Korea's automobile indestry is focused not only on the manufacture of parts and supplies, but on a full-fledged assembly of finished automobiles, which is difficult to find in a semi-periphery. Third, duc to the relatively small domestic market, South Kurea's automobile industry las engaged in experts to gain necessary economies of scalc. Fourth, Soutl Kurcan automubile exports have been based more on price competitiveness than on technological advance's, although this pattern has begun to change recently. Price competiciveness is usually found as a comparative advantage for a semi-periphery in less capital-and technology-intensive light manufactured industries, in a buyer-driven commodity chain (BI)CC). In other words, the South Korean automobile industry does not show the typical characteristics of a PDCC. Finally, large domestic corporations rather than transnatimal corporations (TNCs) have dominated the South Korean automobile industry, and developed indigenous technology and moxtcls.

The paper's goal is ro demonstrate, by analyzing South Korea's automobile industry, how a semi-periphery an successfully develop an auromobilc industry without its own basis of advanced technology or large accumulation of capital. The paper will utilize

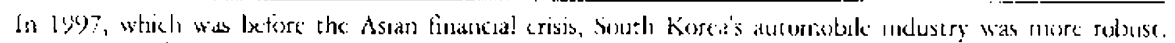

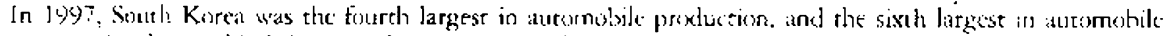

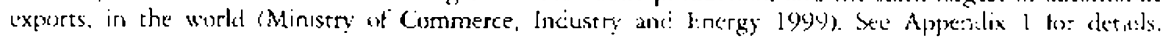


the global commodity duains perspective with an emphasis on its governance structure, the PDCC. The paper is organized into three major parts. Section II provides at brief overvicw of the PIXC analysis of the automobile industry as a tramework tor analysis of the South Korean case. Section III presents an overview of the South Korean alutomolile industry's development. Indigenous research and development efforts, as well as government policies are examined in order to shed light on how South Korea's automobile industry developed its own technology and models. Section IV focuscs on the South Korean automobile industry in the global network of production and sales. The conclusion analyzes key teatures of the South Korean automobile industry, which distinguish it from those found in core nations, and in particular, from a PDCC:

\section{AUTOMOBILE INDUSTTRY: THE PRODUCER-DRIVEN COMMODITY CHAIN}

The global commodity chain perspective, which traces the globalizel production and sale of a commodity, is very useful in analyzing an industry such as autonobiles. Industrics are increasingly coordinated at the global level, where acquisition of raw material, production of parts, assembly of final products, marketing, and sales often occur in different geographical nodes. Such comparmentalized production and sales requirc a high level of administ rat ive coordination by diverse corporate accors (Gereffi 1994, 19)6; Rabach and Kim 1994). Key factors of this globalized producrion system are that the large firms simultaneously particjpate in many different countries, and their artivitics are coordinated "not in an isolated or segmented fashion but as part of their global production and distribution strategies" (Grereffi 1994, 96). According to Gereffi, global commodity chains have three main dimensions, which are as follows:

(1) in input-output structure (i.e., a set of products and services linked togrerher in a sequence of value-adding economic activities);

(2) a territoriality (i.e., spatial dispersion or concentration of production and distribution networks, comprised of enterprises of different sizes and types); and

(3) a governance structure (i.c., authority and power relationships that determine how financial, material, and luman resources are alloxated and flow within a chain) (Gereffi 199) $4,96-97$ ).

Research using the global commodity chain has identified two distince cypes of governance structures, "proxlucer-driven" and "buyer-driven" commodity chains. A key difference berween the rwo is that the former commotity chain is coordinated and controlled by large-scale producers of capital-and technology-intensive commolitics, while the latter is coxordinated and dominated by "large retailers, brand-named merchandizers, and trading companies" (Gereffi 1994, 97). In the latter, production networks are typically scattered throughout the 'l'hird World, where labor-intensive industries previdl to take advantage of cheap laburs costs. 
PDCCs are found in capital- and technology-intensive industries such as automobiles, computers, aircralt, and electrical machincry. In this governance structure, production is controlled by "large integrated industrial enterprises" or INCs (Gertfi 1994, 97). For example, the production of automobiles in the Inited States is controlled and coordinared by the Big Three automakers (General Motors, Ford, and Chrysler Corporation). These large automobile TNCs coordinate everything from production design, and rescarch and development $(\mathrm{R} \& \mathrm{D})$, to product innovation and markering.

This structure differs from BDCCs, whose proxluction is coordinated by large-scalc buyers." For example, garments, footwear, toys, and consumer electronics are produced in various Third World councries under original equipment manufacturer (OEM) arrangements. Here, product design and product innovation are not carricd out by the producers as in the PDCCs, but by the key buyers; bence, the name BI)CCS.

The automobile industry is a prime example of a PIXC. I Due to its capital-and technology-intensive narure, the industry is often found in core nations. If it is found at all in the semi-peripheral nations, it takes the form of lower-end and labor-intensive parts production or assembly, rather than the production of a finished product (Biggart and Guillen 1999):- Automobile production requires numerous parts, from low-tech and Jabor-intensive parts such as seats and mirrors to high-tech and capital-intensive conpurerized equipment and engines. Thus, the production of various componenes of the aucomobile can te dispersed in countries with different positions in the international division of labor, from semi-periphery to core economies. As strown in Table 1, automobile producers in differenc countries exhibit different coordination systems tor sub-contraxtors and subsidiaries.

TABLE 1. (COOPERATION ANDL DIVISTON OH LABXK

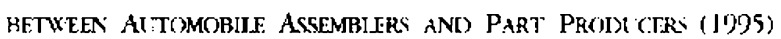

\begin{tabular}{|c|c|c|c|}
\hline & South Korea & Japan & l.S. \\
\hline Rario of Outsourcing & 65 & $i()$ & 40 \\
\hline Seructure of Suprly Network & Single Stage & Mulipuis St ages & -1 \\
\hline Means of Sourcing & Multi-Sourcing: & Single-Sorurcing & Multi-Sourcing \\
\hline Deprec of Cosperation & Middle & Hight & I.MW \\
\hline
\end{tabular}

Sharce: Korea Institate ror Industrial Econonucs and Tadte. 19y)?a, 36,5

Another importane feature of PDCCs is that their profits derive from large-salc production and technological advances (Appxlbaum and Gereff 199\%, 41; Gireffi 1991, 99). Mass production is representative of PICCS, while flexible protuction characterizes BDCCs. The South Korean case represents significant variations from previous studies on PDCCs. First, it is an unusual case in that as a semi-peripheral nation, ic has engaged in the production of a final product as well as in the less capital- and technology-intensive parts (Biggart and Guillen 1999). Second, domestic conglomerates, the diutol, dominate

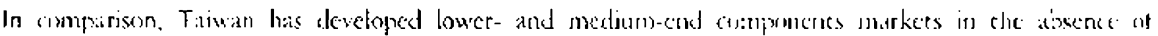
a stobstantial assembly sccost Biggiter and Civillen lyly): 
the automubile industry in South Kurea, while TNCs dominate other semi-peripheral industries in countries such as Brazil and Mexico (Park 19)99). Third, South Kored crcated its own modeI and indigenous technological development as a consecjuence of low TNC. investment and the domination of chabol (Park 1999). These characteristics make the South Korean automobile industry an interesting case to broaden our understanding of a PDCC in a semi-periphery, and to challenge key arguments in the PIXC andysis.

The latter part of this paper deals with the South Korean automobile industry's governance structure and linkages to domestic suppliers, sub-contractors, and forcign partners tor capical investment, technology transfers, and tracke. The findings will help us ascertain to what extent Sourh Korea's experience can be replicated in other developing countries who aspire to upgrade their industrial structure by engaging in capital- and technology-intensive industries.

\section{SOUTH KOREA'S AUTOMOBILE INDUSTRY: AN OVERVIEW}

Appelbaum and Gereff (199) noted that the active support of the government, including financial suppore and tax exemptions for the promotion of exports, was critical in the develepment of South Korea's automobile industry. Also, Biggart and Cuillen (1999) pointed out that the "producer-driven" automobile indust ry in South Korca resulted from prorectionise state policies, which were favorable to the thatol or large business gruups such as Hyundai, Daewoo, and Kia.

The South Korean automobile industry began with President Park Chung Hee's (1961 - 74) ambritious plan to develop it as a key part of the broader securicy industry. In addicion to fimancial support and tax exemptions, the government gujded the stages of industrial development by establishing legistation to support and promore the automobile industry. It implemented protectionist strategies such as limiting imprurts of parts and banning imports of finished cars during the early stage of development. To hedp domestic producers achieve economies of scale, the government restricted the number of firms or new entrants into the automobile industry.

South Korea's automobile industry went through the following tour stages: 11 knockdown kit assembly (1962-76); (2) localization of production and development of local models (1976-86): (3) mass production and mass export (198694); and (4) operuing of the domestic market and globalization (1994-present) (KJET 199? a). In this paper, we brictly review the hiscorical background and focus primarily on the fourth stage in which South Korea's automobile production and sales became globalized.

The South Korean automobile industry began in the 1960 s with simple knockdown assembly.; The Auromobile Promotion Law and Automobile Industry Protection Law were announced in the early 1960) along with the Five-Year Econonic Development Plan. These laws were designed to improve the local content ratio and to restrict imports

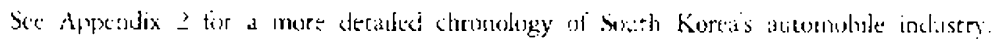


of foreign cars and parts. Artaining economies of scale was an important issue in the initial stage of the automobile industry as well. 'l'hus, only one manufacturet was allowed wo produce cars to achicve the requisice economy of scalc. Sacrara Motors was the first automobile producer in South Korea.

In 1967, the government began to allow ocher manufacturers to produce cars, and consequently. Hyundaj Motors, Kia Motors, and Asia Motors 4 entered the domestic car market with technological alliances with Ford of the U.S., Fiat of ltaly, and Mazda of Japan, respectively. However, a limited production capacity and a small sized domestic market did not make South Korea an attractive site for forcign investors. Thus, foreign automobile producers tended to introduce models that failed in the global market, and did not make substantial investments in South Korea. As a result, expectations that these 'INCs would contribute toward a leapfrog movement of industrial upgrading did not occur, and gradually the South Korcan automobile industry came 10 bx dominated by domestic corporations with ties to the abaknl.

Highlights of the second stage include the introduction of the Long-Term Automobile Industry Development Plan in 1973, and the Long-Term Automobile Industry Promotion Plan in 1974. These laws were intended to promote the development of South Koreas indigenous models and raise the ratio of domestic production. During the third stage, mass production of automobiles based on local models, and mass export began. Due to decreased demand as a result of two Oil Shocks in the 197t) and domestic political turmoil, the automobile industry went through major restructuring in the carly 1980 s. The government finally allowed only two automobile producers to manutacture passenger (ars until 1987.

In 1986, the first shipment of Hyundai cars was exported to the United States. As South Korea's automobile producers exported 3 billion cars that year to the United Stares, they achicved economies of scale for mass probuction. By $1 \% 95,51$ percent of all South Korean automobile sales were for exports, compared to :19 percent for domestic sales (Park and Kim 1997; Sadler 1999). In the U.S. market, South Korean automobiles were distributed by Hyundai's tegional offices (via Hyundai Motor America) and original equipinent manufacturing (OEM). OEM has been the major stracegy usced by INCs in re-exporting autornobiles asscmbled at of thhore plants to core nations. Hyundai employed a strategy that utilized its conglomerace business organization to create the initial impulse for cxport. In addition, irs marketing strategy revolved around lower prices compared to other comparable cars, and was oriented toward the lower-end of the auto marker. Sales were conducted through single-point dealerships specializing in Hyundai's cars, and rhese dealerships were organized around a strategic sales network concentraced in three regional offices-Los Angeles, New York, and Atlanta which switched to Chicago in 1989) (Gereffi 1994, 291). The relatively low price compared to car quality, and the marketing strategy of South Korean autumobile companies, account for the sizeable

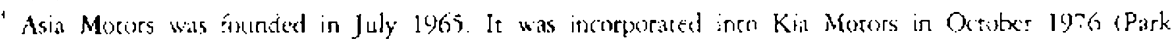
199.4. 451 
market share of South Korean automobile firms in the U.S. and Canadian markets (Kin 199?). ${ }^{5}$

Mass production and mass expore enabled the South Korean automobile producers to actively seck alliances with automubile TNCS. They also increased R \& D investment. Since 1991, when South Korea's domestic automobile market wis liberalized, the South Korean auromobile producers have implemented various glohalization srategres and increased their overseas foreign direct investment. After the Asian tinancial crisis of 11)9? thobalization efforts escalated with a series of merger and acquisition ( $M$ \& A) activitics and technical licensing with WNCs. There were also vigorous restructuring efforts in (Irder (w) increase capital, reduce debt-equity ratios, and improve busincis performance. Figure 1 slows some examples of $M \& A$ activities anong the leading automobile producers in South Korea including the recent acquisition of Samsung Motors by Renault, Hyundai's incorporation of Kia, and a more active technical alliance betwecn majur domestic companies and foreign automobile producers.

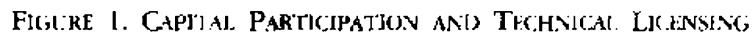
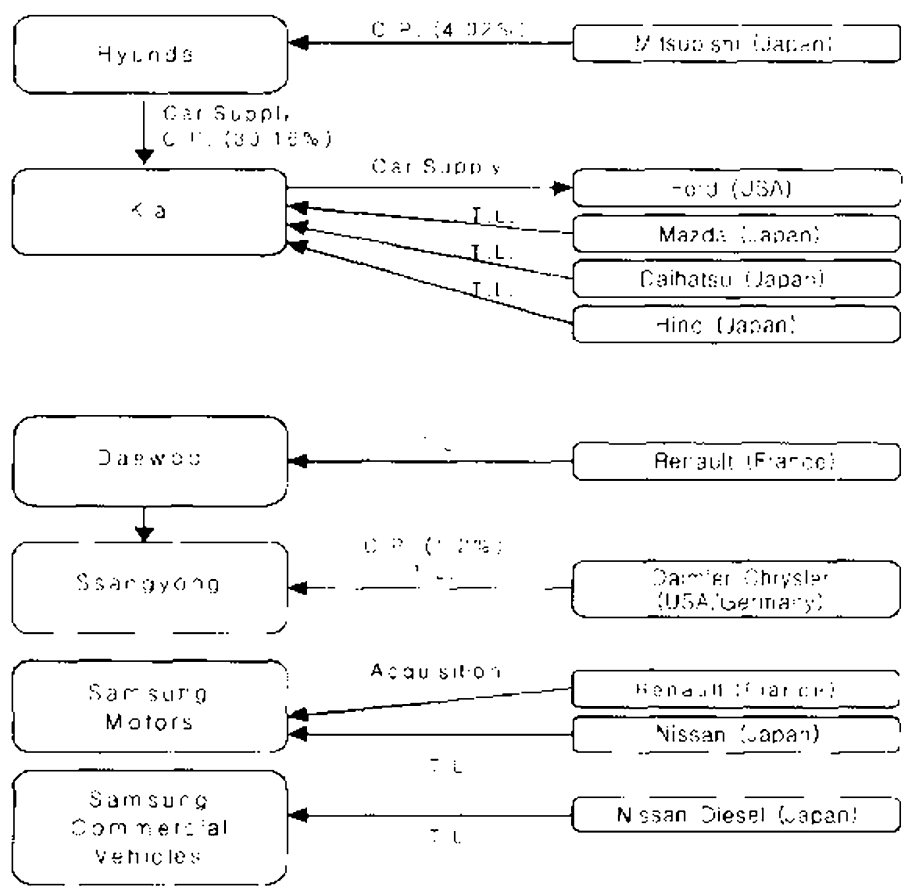

Note: C.P. denutes capical particjpation; T.L. denceses [eshomic al licenstiog-

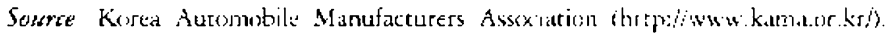

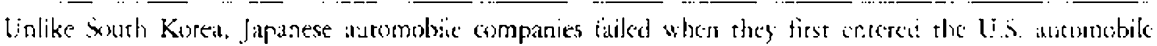

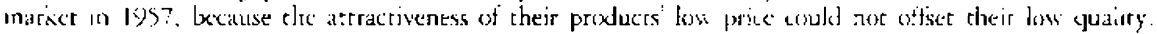

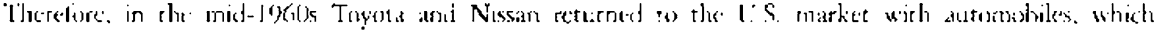

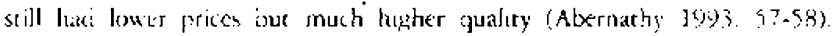




\section{SOLTH KOREA'S AUTOMOBILE INDUSTRY IN THE GLOBAL COMMODITY CHAIN}

"The automobile is probably one of the most complex connoditics that can be analyzed" from the glubal commodity chains perspective (Iexe and Cason 199\%, 227). Automobile production can be classified roughly into the following four processes: (1) raw material proxessing; (2) raw material, parts, and components fabrication; (3) body, component stamping and fabrication, and metal casting; and (4) kngine, transmission, and other systems and sub-systems (Morales 1994, 27-28). Thus, it represents one of the most diversified production processes, requiring a high level of coordination often in a multitude of geographical nodes.

Due to the complexity of automubile production, Lee and Cason (19) 4,227$)$ suggrest that the automobile industry should be subdivided into three broad segments: (1) parts supply networks; (2) axsembly production nerwork; and (3) marketing networks. This classification is a revision of the four segments proposed by Gereffi and Komeniewicz, which include raw material supply, production, exporting, and marketing and retailing ( 1990,51$)$. Since exporting occurs at several differcnt stages of the commodity chain, such as that for parts and finished products, Lec and Cason (1994) argue that exporting should not be separated, but integrated into all three segments. In this paper the parts supply network will be examined rather chan raw material acyusition, which is vory difficult to identify.

The following scction discusses the three broad segments Iee and (atson suggest in terrns of the automobile PDCC in South Korea. In order to lighlight the globalization of auromobile producers, we revised lee and Cason's (1994) framework: the markering network is broadened to globalization of production and marketing. In the larter schment, we examinc capital investment, technology transfers, exports, and overseas forcign direct investment as the tour most important forms of globalized linkages. South Korea's automobile production is examined with a special emphasis on its litkages to the U.S. and japanese aucomobile producers.

\section{Parts Supply Netuorks}

The strong developmental state in South Korea protected donestic industries especially during the early stage of industrialization, and festered the growth of the chathe. Ihe aucomobile industry was 16 exception. In fact, it was protected from imports of both parts and finished products, thus allowing an extensive domestic production network to develop with the thathl at the center (Biggart \& Guillen 1999).

The assembler has the following three oprions in meering denands for pares and components. It can produce the parts and components in its own factories, outsource rhem to subcontractors, or purchase the necessary parts and compunents from supplicrs. The second and third opeions are differene since the second is based on a very extensive hietarchical relationship between the assembler and parts producers. The L.S. autonwobile 
producers tend to follow the third model, while South Korean and Japanese automobile produces follow the second model, with a relatively high ratio of parts and components obrained from suldontractors as shown in Table 1 (Cho I\$981.

The subcontractor system in South Korea and Japan is discinct from other countries. Japancse automobile assemblers bave an extcnsive nulti-layered subentracting systcon. In South Korea, although sulxontractors are independent legal encities, the extlusive linkagres and the presence of dominant assemblers, which are chaernl firms. force the subcontractors to behave like affiliates of the assemblers (Cho 1998; KIFT 1997b). For example, an assembler can reduce cransaction costs by threatening to forcibly throw out a supplier, andior demand better performance from a supplier. But the supplier has no such chonce or autonoryy to change the assembler. Moreover. the assenbler, in order to maintain an exclusive linkage with subcontractors, dexs not allow the sulxontracturs to set up new linkages with other assemblers (KIFT 195) b, 23-28). The: assemblers control the exit and entry of the sutwontracturs in their network (Who 1998). This kind of a supply network lacks flexibility and transparency (Cho 1048). Fair competition based on free market principle is not practiced in rhe South Kortan automobile asscmbler-supplier relationship.

The Suuth Korcan government played an important role in the development of the subcuntractor network. In December 1975 the government promulgated the Law to Promote Intertirm linkages of Small- and Medium-Sized Enterprises, which was followed by specitic policies and subsidy plans in 1976. In 1977 the South Korean governmente designated the atumomile indusry as one of the induseries protected by this law. The policies were intended to promote horizontal nerworking among automobile parts producers. The goal of law and policies was to protect the small- and medium-sized automobile parts producers by preventing both thatbol automobile assemblers from producing parts and 'INCs from penetrating the South Korean market (Park 1949). However, the law was perceived to entance the autonorny capacity of automobile parts prexlucers at the expense of automobile assemblers. Thus, in 1975 due to léay opposition from powertis autombile assemblers, the law was revised to allow a "vertical" over a "horizontal" relationship. This meant that the ibabol automobrile producers could orgarnize the subontractors under its control in a vertically hierarchical network. In $197 \%, 15$ automobile parts were designated for incorporation into a hicrarchical network. In 198032 parts, in 1985274 parts, and in 1991326 parts were designated (Park 1(x)s). As a result of this revised law, the wealth and influence of the chaterol automobile assemblers grew tremendously. Thus, in South Korea. a disparate relationship berween the assembler and subxontractors developed, in which the former exered too mud conerol over due latter, in latge part due to goveremene pulicies.

As shown in Table 2, an owerwhelming majority of automobile pirts producers work with only one or two automobile assemblers. In facr, over 84 pxercent of all parts producers work with less than two assemblers. This shows an increase from 78.4 percent in 1996 , which reflects a growing concentration of automobile assemblers and the increasing dependence of parts producers on them. 
TABLE 2. LINKACIES BETWEEN ALTOMOBILE PAKT PROUUCFRS

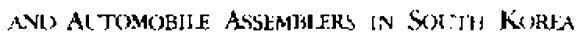

\begin{tabular}{|c|c|c|c|c|c|c|}
\hline Number of & \multicolumn{2}{|l|}{1996} & \multicolumn{2}{|l|}{1999} & \multicolumn{2}{|c|}{ Change (149)(6-1999) } \\
\hline $\begin{array}{l}\text { Autumobile } \\
\text { Assemblers }\end{array}$ & $\begin{array}{c}\text { Number of Parc } \\
\text { Producers }\end{array}$ & $\begin{array}{l}\text { Share } \\
(\%)\end{array}$ & $\begin{array}{c}\text { Number of Part } \\
\text { Producers }\end{array}$ & $\begin{array}{c}\text { Share } \\
(\%)\end{array}$ & $\begin{array}{l}\text { Number of Part } \\
\text { Producers }\end{array}$ & $\begin{array}{c}\text { Shate } \\
(\%)\end{array}$ \\
\hline 1 & 6,57 & 57.1 & $5 ? 0$ & 659 & $y=$ & $8 . r$ \\
\hline 2 & 245 & 21.3 & 158 & $18 . ?$ & -8 & $+3 i j$ \\
\hline 3 & 104 & 9.5 & si) & 9.2 & -20 & -0.3 \\
\hline$\dot{4}$ & 5) & 3.1 & 57 & 6.6 & -2 & -1.5 \\
\hline 5 & (10) & 3.5 & & 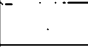 & in & 3.5 \\
\hline 6 & 23 & 2.0 & & - & 23 & -2.0 \\
\hline$?$ & $1 ?$ & 1.5 & - & $-\ldots$ & -17 & -1.5 \\
\hline Toral & 1,150 & 100.0 & 865 & $: 00,0$ & .285 & - \\
\hline
\end{tabular}

Sratce: Korca lostiute for Indeseria. Economics and Trade. 19y?h, 21.

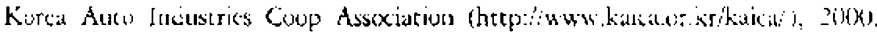

A strong domestic production network of parts firms makes it nearly impossible for foreign suppliers to penetrate the industry. Furthermore, domestic parts producers are not interested in the international market; they enjoy a strong and steady demand for their product due to the state's policy for a high local content ratio. In 1988, the loxal content ratio of a tinished product for the domestic market was $90-95$ percent, and 80-85 percent for the export market (Gerefi 1994, 229). Although cars fur cxport reveal a slighrly higher proportion of imported parts in order to nece forcign consumers' expectation for higher quality and taste, it is still considerably lower than that of their counterparts in other newly industrializing countries (NICs). For example, in 1988, foreign parts in automobiles tor export constituted $30-40$ percent in Brazil and $45-70$ percent in Mexico (Gereffi 1994, 22) ).

However, it is misleading to regard the high local content ratio of South Korcan automobiles as a retlection of the high level of maturity and independence of the Suth Korean automobik industry. In fact, South Korea's automobile industry is still hearily dependent on forcign technology for the most crucial parts and doxs not have inany advanced indigenous models (Lee 1995, 108; ITEP 19)6, Park and Kim 1997, 73) showed that although the total export of automobile parts increased over 16 percent between 1993 and 1995 to over $\$ 2$ billion, imports increased even faster. What is more alarming is the fact that imports of engine and chassis parts increased sharply, resulting in an increased trade deficit in these two areas (Park and Kim 1997, 73). Figures in Table 3 display the trade patterns of various automobile parts in the mich-1990s.

rependence on forcign marsufacturers for parts in automobile export is even higher (sec: Table 1). The Korea Institute of Industrial Technolugy, Fvaluation, and Planning (IIEP) (1996) calculated the dependency rate for important parts, and revealed that one of the most technologically advanced parts, the power transmission, had a dependency rate of 50 percent, 85 percent of which was on Japanese manufacturets (ITEP 1946, 44). The findings in Table 1 illustrate that South Korea's automobile industry continues 
to tx heavily dependent on imported parts from Japan, the United States, and Crermany when dealing with the high standards for automobiles in export-kestination countries such as the Linited Srates and Canada.

TABIE 3. IMPORT AND EXPORT OH AITOMOHIIE PiRTS IN THE SOLTH KORFAN ALTOMOHLI: INE) SIRY

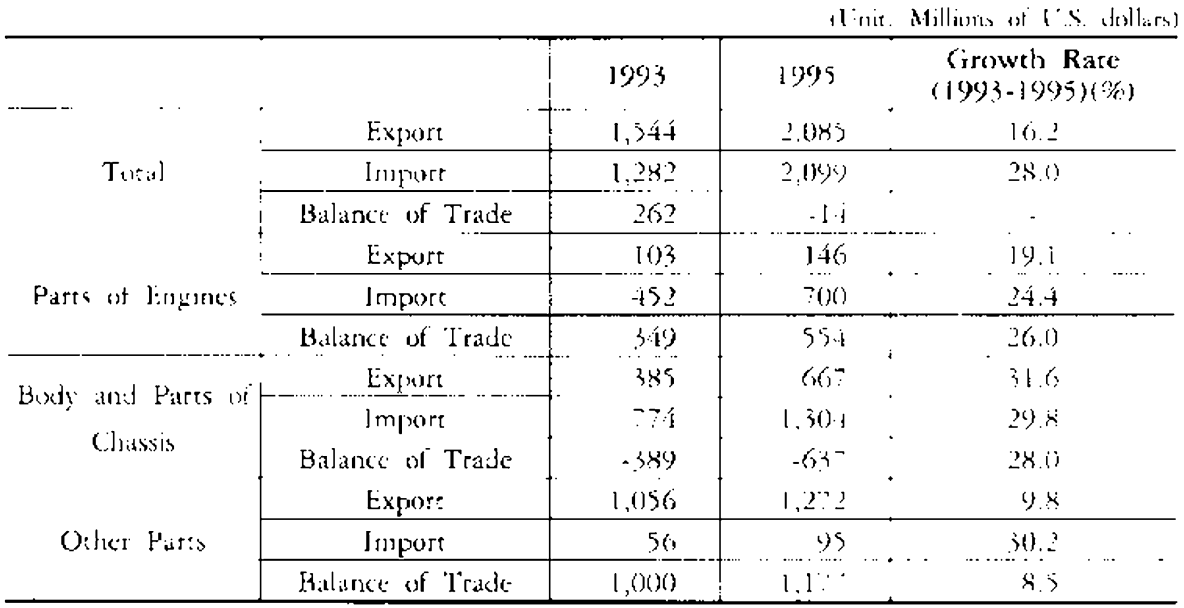

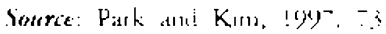

Overall, South Korea's automobile parts production is oriented primarily toward the domestic market. Sixty-five percent of parts producers responded that they do not export at all. in a poll conducted by the Korea Institute for Industrial Economics and Irade. (KIEI) (Park and Kin 199\%, 71). Even when they expxort, over 30 percent of the firms replied that the sthare of exports in total sales is less chan 25 percent (Lbid. 7(6). Thus, the predominant marke for Souch Korca's autumolile parts producers is domeseic auromobile companies, and not the world market. Findings confirm that the automotile parrs network is heavily domestic with low levels of globalization.

Nonetheless, South Kurea's highly integrated domestic autumobile parts network is experiencing pressure ro globalize, as cheaper automobile parts are avalable from the Association of Southeast Asian Nation (ASEAN) member economies (Cho 1948, 19-22). In response, the South Korean automobile parts producers have invested overscas is urilize cheaper latxur costs in the earlier stage. The figures for average investment per case reveal that North American parts suppliers are more appital-and rechnology'-intensive than these in other regions. They indicare that the more technologically advanced parts are produced in the core, while the more labor-intensive parts are produced in the semiperiphery and periphery countries.

Recenty, overseas automobile parts production has accelerated with the brovider globalization strategies of South Korean conglomerates. who seek nor only theap lalxor and input costs, but also access to emerging markets. Table 5 shows the diversification of the averseas parts supplices' network in 1995, in which dhe People's Republic of China 
TABIJ: A. DEPENDENCE ON FOREIGN AUIOMOHHIJ. PAKTS IOK AITTOMONIJES FOR EXTORTS (1962)

\begin{tabular}{|c|c|c|c|c|}
\hline \multirow{2}{*}{$\begin{array}{l}\text { Automobile } \\
\text { Parts }\end{array}$} & \multirow{2}{*}{ Imported Contents and Country of Origin } & \multicolumn{3}{|c|}{$\begin{array}{l}\text { Dependency Rate on Foreign } \\
\text { Ausomobile Proxducer }\end{array}$} \\
\hline & & Japan & $\begin{array}{c}\text { Other } \\
\text { Coustries }\end{array}$ & Total \\
\hline $\begin{array}{l}\text { Power } \\
\text { Generater }\end{array}$ & 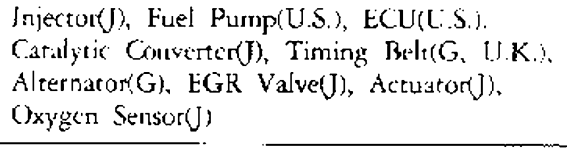 & $2 \cdot 4.5$ & 10.5 & $3)$ \\
\hline $\begin{array}{l}\text { Powas } \\
\text { Trarssmission }\end{array}$ & 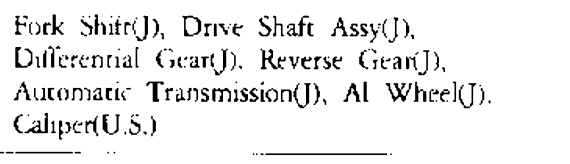 & 42.5 & 75 & 50) \\
\hline Chassis & $\begin{array}{l}\text { Power Stecring Pump(J), Flexible Hosed. U.S.), } \\
\text { Clutch Disk(U.S.), ABS(U.S.), TiretU.S.) } \\
\text { Bumper Board(G) }\end{array}$ & & & 10 \\
\hline Body Fittings & 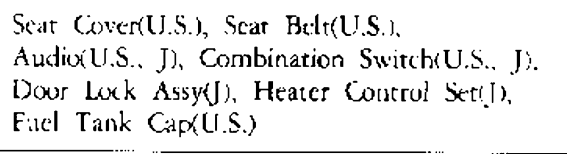 & 8 & 12 & 3 \\
\hline Total & & 1.1 & 6 & 20 \\
\hline
\end{tabular}

Dose: J derores Japan; Li.K. denotes Linited Kingdon; U.S. denvies limited States; of denores Cormants.

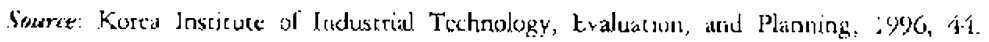

TABIF 5. ONFRSES PART St:PPIY NETW(IKK ( $H$ : SUlTH KOREAN ALTOMOBILE PART PRODI ICERs (19)5)

\begin{tabular}{|c|c|c|c|c|c|c|c|}
\hline & \multicolumn{2}{|c|}{ Cases } & \multicolumn{4}{|c|}{ Invesment } & \multirow{3}{*}{$\begin{array}{c}\text { Average } \\
\text { Investment } \\
\text { per Case } \\
378.9\end{array}$} \\
\hline & Number & $\begin{array}{c}\text { Share } \\
(\%)\end{array}$ & (in & $\begin{array}{l}\text { Amount } \\
1,000 \text { L.S. }\end{array}$ & \$) & $\begin{array}{c}\text { Share } \\
(\%)\end{array}$ & \\
\hline ASEAN & 57 & 33.0 & & 14.019 & & 18.7 & \\
\hline Maliaysia & 7 & 6.3 & & 2,702 & & 3.6 & 3860 \\
\hline Indunesia & 7 & 6.3 & & 6.634 & & $x .9$ & $94 \% ?$ \\
\hline Thailand & 2 & 1.8 & & 601 & & 0.8 & 300.5 \\
\hline Philipgines & 20 & $1 ?: 9$ & & $H_{1}, 0 \times 2$ & & 5.4 & 204.1 \\
\hline Viermans: & $\mathrm{I}$ & 0.9 & & 0 & & 0.0 & 1) \\
\hline China & 59 & 52.7 & & 40,941 & & 54.6 & 693.9 \\
\hline North America & 7 & 6.3 & & 7.255 & & 9.7 & 1036.4 \\
\hline L:S. & 6 & 5.4 & & 3.655 & & .9 .9 & 609.2 \\
\hline Ocher & 9 & 8.0 & & 12,712 & & 17.9 & 1.912 .4 \\
\hline Total & 112 & 100.0 & & 74,927 & & 100.0 & 669.0 \\
\hline
\end{tabular}

Source. Pits and Kim, 19y? I5. 
became an important supplier. ASEAN countries and the Unied States alre also suppliers, albeic on a smaller soale than China. Access to China and ASEAN redlects the South Kurcasn automobile producers desire to move to new umerging markets, as the veder markets are beroming increasingly saturated.

\section{Assembly Production Netuorks}

Assembly production in South Korea began in the early 1960). South Korca's automobile industry developed differently from other NIC chrough an extensive domestic production network. South Korea's automobile industry was escablished with domestic capital since the automobile producers from the cote nations were not intetested in investing in South Korea due to the inport substitution industrialization (ISI) strategy of the Syngman Rhee governmenc (19/48-60). Furthernore, other Fast Asian countries delivered more, atractive investment conditions, enticing major automobile TNCs to invest in other areas (Kin and Lee 1994, 285). Even when the South Korean government's industrialization policy shifted from inward- to outward-oriented stracegies in the mid1960s, regulations and restrictions on the amount of toreign capital investment allowed in the domestic industry made it difficult for foreign dirce investment to take hold.

In keeping with the South Korcan government's reluctance to completely open the domestic automobile warket to TNCs, South Korean auromobile producers were slow to fully cmbrace thije counterparts from core nations. However, wirh new santrants, it became imperative that the South Korean automohile producers inpore technolugy from automobile producers in the United States and Japan. At the lxyinning, South Korean automobile producers acquired capital from the American Big Three autonakers and Japanese automobile producers. In the case of Hyundai, the company mairtained at policy of kexping its brand name and self-identity in its products. In 1968 , 1 lyundai signed an agrexment for a 5 -year technical collaboration with the paynent of one to three percerte royalties. Since l iyundai recognized the inoportance of foretign technologry as a late entrant in the alitomobile indust.y, it hat to negotiate for a $50: 50$ joint venturs: with Ford, but the three-year long negotiation ended in failure in 19?2. Hyundai did noe want a joint venture at the expense of domestic manigerial control. Hylindai decided to acquirc technologies by licensing rather than joine ventures, and in 1979, established its own R \& D center. To meet the quality standards of major car markets, ly yundai also licensed more than thirty different technologies from Japan, England, and the Lnited States, with mixed results (Kim 1992). It later signed a strategic alliance agrecenent with Jayan's Mitsubishi Corporation, which was mainly in cnginecring, manufacturing, and marketing.

On the other hand, Dacwix Motors, from the beginning, entered a 50 percent joint venture with Gencral Motors (GM) and imported models and technology ifeveloped by GM for its world car concept.

In the 1980s, South Korean automobile producers emerged as new competitors in the international market, and the first stage of globalization of South Korean auromobiles 
bxgan. South Korcan automubile producers currently display increasingly cooperative relarions with TNCs in terms of capital and rechoology.

Although there were vigorous efforts for indigenous $\mathrm{R} \& \mathrm{D}, \mathrm{T}$ able 6 show that South Korean automobile producers were heavily dependent on Japancsc producers for technology. The figures for technological alliances prior to 1987 reveal a staggering 185 cases from Japan compared to 43 from the United States and 31 from the Unitcd Kingdon. More recent figures show that the overall dependence on foreign firms has decreased. Nonctheless, the figures for $1(y) 2$ continue to show that Japan is the most important partner for techoological alliances. It is interesting to note South Korea's greater depersdence on Japanese prokkers than on the Cinited States producers. However, this is not that surprising since mid-level managers and floor-level workers prefer to work with Japanese firms due to their superior after-service plans and overall familiarity with the language and culture compared to those of the U.S. firms (F. M. Kim 1997, 84-89).

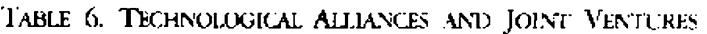

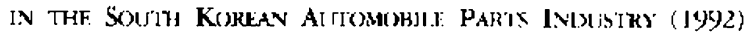

\begin{tabular}{|c|c|c|c|c|c|c|c|c|c|c|c|}
\hline \multirow[t]{2}{*}{$\begin{array}{l}\text { Partmer } \\
\text { C.nunaries }\end{array}$} & \multicolumn{2}{|c|}{$\begin{array}{c}\text { Before } \\
1987 \\
\end{array}$} & \multicolumn{2}{|c|}{1988} & \multicolumn{2}{|c|}{1989} & \multicolumn{2}{|c|}{1990} & \multicolumn{2}{|c|}{1991} & 1992 \\
\hline & $T A$ & $\mathrm{JV}$ & TA & JV & $\mathrm{TA}$ & $\mathrm{JV}$ & İ & $\mathrm{JV}$ & $T A$ & JV & $\mathrm{TA}: \mathrm{JV}$ \\
\hline Japan & 185 & 39 & 28 & 13 & 19 & 9 & 32 & - & 17 & $\vdots$ & $22 \quad 1$ \\
\hline $1 ! S$. & 43 & 19) & 15 & 9 & 7 & 11 & $\neg$ & - & 6 & 2 & 10 \\
\hline Germatly & $? ?$ & 6 & 2 & $?$ & 3 & 6 & 12 & $?$ & أَ. & 1 & 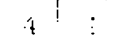 \\
\hline U.K. & 31 & $?$ & A & - & 1 & 1 & 8 & - & 2 & 2 & 6 \\
\hline Oener & 14 & 2 & 5 & 2 & 3 & 1 & 6 & 1 & 2 & & 3 \\
\hline
\end{tabular}

Note: TA denores Iachnological Alliarues; Jo denores Joint Ventutes.

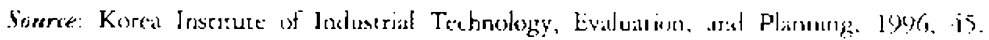

Table? presents the South Korean automobile producers' alliances with foreign automobile producers. The findings show that Japancse automobile makers are very popular among Souch Korcan automobile producers. Since 1997, many of the U.S.-based automobile TNCs have exitced South Korea.

A report from the Korca Institute of Industrial lechnology Evaluation and Planuing (ITLP) on the technological development of the Sxuth Korean autonwbile industry takes note that although the South Korcan-developed models are sold around the world, critical software in designing and developing new models comes from abroad (see Table 4). The findings in Tables 4 and 7 indicate that both in technological alliances and imported pares, the South Korean automobile industry relies hedvily on the Japanese automobile indusery.

Figures in lable 8 show that the share of $\mathrm{R} \& \mathrm{D}$ in total investment grew over rime to over 36 percent by 1997 . This is an encouraging sign that South Korea's automobile industry is attempriag to upgrade its products. 


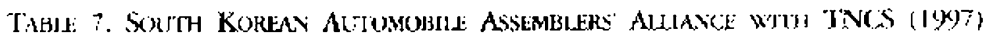

\begin{tabular}{|c|c|c|}
\hline 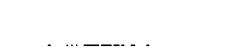 & Contents & TNCs \\
\hline \multirow{3}{*}{ Daewan Motors } & Technology & Honde (Assembly) \\
\hline & Parts (Production! & GiM (Bartery) \\
\hline & Pares (Technology) & 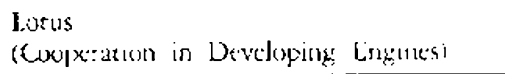 \\
\hline \multirow{3}{*}{ Hyuntia } & Capital Cooperarion & Mitsubishij \\
\hline & Technology Iransfer & $\begin{array}{l}\text { Musubistij } \\
\text { (Engintering, Manufacturing Tohnulogy) }\end{array}$ \\
\hline & Capical Coxoperation & lootd. Maria \\
\hline \multirow[t]{2}{*}{ Kia Motors } & Sales & Ford \\
\hline & Technology Transfer & Mazda (Parts, Englneering) \\
\hline Samsung Motors & Technolngy & Nissan (Finginectring, Manufacturing) \\
\hline \multirow{3}{*}{ Ssangsung Morars } & Capital & Mercedes-Benz \\
\hline & Texhnalogy & Mercedes-Benz (Van, Engine) \\
\hline & Sales & Mercedes-Ben \\
\hline
\end{tabular}

Soufce Park and Kim 199? 35.

TABLE 8. R\&D INVESIMENT IN THE SOLTH KOREAT ALTOMOBII.F INDT STR

(Linir: Billiso Korean Won)

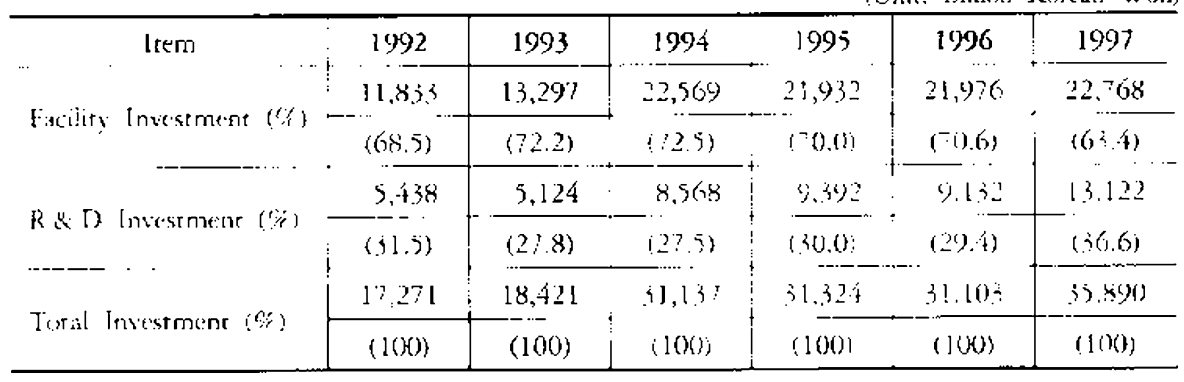

Sonrce: Korea Automobile: Rescarch Insticuce, 1997.

Figures in 'Table 9 show that the Japanese automobile firms' sharc of $R$ \& $D$ isvestment relative wo rotal sales was greater than that of most other countries' automobile firms from the late 1980s to the early 1990s. But due to the bursting of Japan's bubble economy and a worldwide recession, most Japancse aucomobile producers decreased their R \& 1 ) investment in 1993 and 1994. Many orher automobile producers shuwed a similar dectine in 1994, while South Korea's automobile producers invested more in $\mathrm{R} \& \mathrm{D}$. Along with the figures in Table 8 , this data reflects growing efforts by South Korea in indigenous $\mathrm{R} \& \mathrm{D}$ efforts in recent years. However, the Asian financial crisis of 1997 , which hit the Sisuth Korean economy quite severcly, no doube acgativety affected $R$ \& D investrmest in automobile production. 


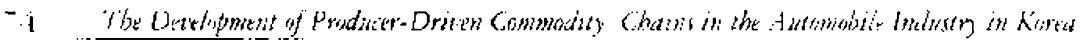

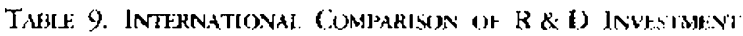

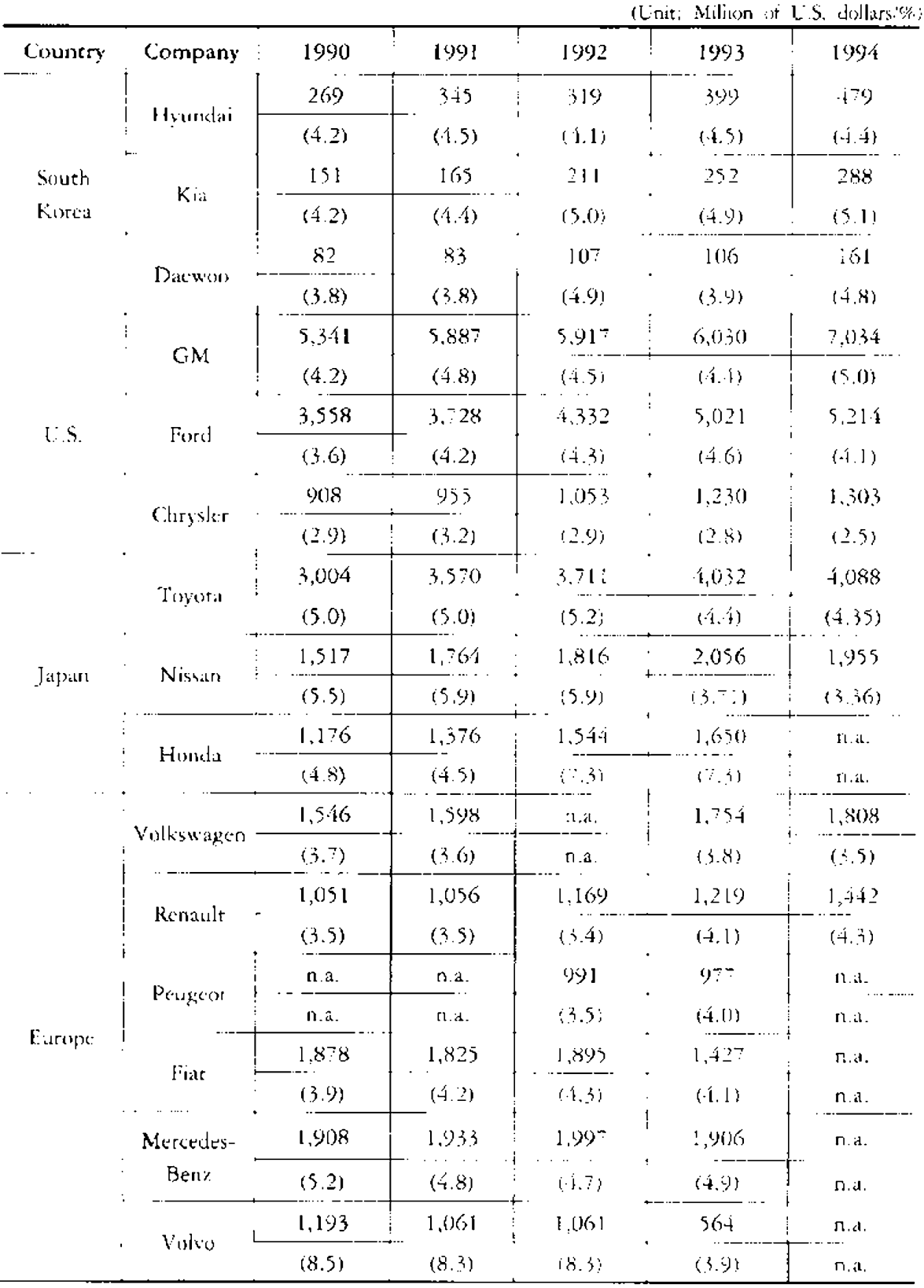

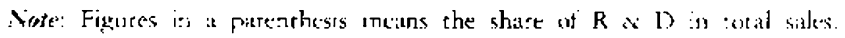

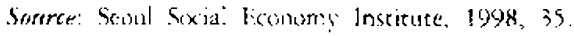




\section{Globalization of Production and Marketing}

In the 190 (ss, South Korean automobile producers begall to actively seck ways to survive in the world market, which was becoming increasingly competitive. The following issues pressured South Korea's producers to build a globalization strategy including ghlobal management (KIET 1997b, 26-29):

(1) Overcapacity: As the domestic market becane too srnall to absorb the production capacity of domestic automobile producers, it was imperarive ro seck overseas markets.

(2) Rising protucrion costs: As wages in the domestic labor market rose, automobile producers sought production sites with more favorable conditions ic.s. cheaper labor and other production costs) in order to maximize profits.

(3) Trade barriers in regional economic bless: The South Korean automobite producers established factories within regional economic bloss to bypass tradc protectionism,

(4) Flexibilicy: In order to respond to rapidly changing market condit ions and consumer preference, it became advantageous to have $R$ \& $D$ bases overseas.

Recently, Hyundaj released a three-staged globalization strategy to enhance its competitiveness (Hyundai Motors 1947). The three stages are: (1) the building of plain complete knoxk down (CKD) sites and exparsion of overseas production sites; (2) overscas foreign direce investment either through a joint ventute or as a single investor and the opxening of local offices abroad; and finally, (3) completion of the global production and marketing nerwork.

Hyundai is constructing the largest overseas manufacturing planc oucside of South Korea in China and India, a CKD production site in Turkey, and assembly plants in China, the (zech Republic, Egypt, Taiwan, Venezuela, and Botswana. Hyundai Mocors will invest about $\$ 1.1$ billion in these sites up to the year 2001 (Website hitcp:// www hyundai-motor.com). As for marketing, while Hyundiai relicel on Mitsubishi's internarional markering network and local dealers in the past, it now has its own international masketing network of 175 distributors in 158 councries worldwide (Ibid.). To copx with the growing demand for Hyundai cars and to bridge the gap in its global network, the company operates an on-line service, providing information about the nearest Hyundai car dealer and part suppliers on its home page (Ibic.).

lable 10 illustrates the extent of uverseas foreign direct investment by the three major automobile producers in 1997 . The figures reveal that fairly large investments werc made in Fastern and Central European countries as wetl as in Chind and India. These investments represent the South Korean automobile profucers' plans for a globalized producrion system, which targer both cheap input costs and access ro emerging markers. Their incerest in emerging markets implies that South Korcan automobile producess continue to rely on price comperitiveness racher than exchnological innowation as their comparative advantage in the global automobile market.

'Table 10 also suggests that all of the investments began in the early to mid- $1990 \mathrm{~s}$, and actual production began only in the late lovos. Therefore, it will take a few mors 
years to evaluate whether the South Korean automobile producers have succeeded in their anbitious globalization plans.

TABIF. 10. ONERSEAS PRODY CTION SITFS OF TIJ: SOITTH KORFAN AITOMOBIIF. ASSEMBILRS ([y)? )

\begin{tabular}{|c|c|c|c|c|c|}
\hline & Region & $\begin{array}{l}\text { Year of } \\
\text { Begimnins } \\
\text { Investment }\end{array}$ & $\begin{array}{l}\text { Year of } \\
\text { Beginning } \\
\text { Production }\end{array}$ & $\begin{array}{l}\text { Amoune of } \\
\text { Investment } \\
\text { (millions of } \\
\text { Lis. dollars) }\end{array}$ & $\begin{array}{l}\text { Proxluction } \\
\text { (apacity } \\
\text { (thousand) }\end{array}$ \\
\hline \multirow{13}{*}{ Dikw(x) } & Indonesia & 1995 & 1495 & 8 & 53 \\
\hline & Uzbekistan & 1993 & 1996 & 658 & 270 \\
\hline & Romaluia & 1994 & 12996 & 495 & 165 \\
\hline & Vietnam & 1993 & 1066 & 32 & 50 \\
\hline & Chind & 1993 & & 30 & 5 \\
\hline & \multirow{4}{*}{ Philippines } & 1994 & 1499 & ris? & 150 \\
\hline & & - & 1040) & 252 & $! 50-3000$ \\
\hline & & 1993 & 1096 & 15 & $1 \geq 0$ \\
\hline & & - & 1996 & 5 & 80 \\
\hline & lndial & 1994 & :3995 & 4) & $2-40$ \\
\hline & Cizech & 1995 & 1990) & 32 & 45 \\
\hline & Poland & - & $\therefore$ & 3440 & 70 \\
\hline & & 1995 & - & 1121 & 255 \\
\hline \multirow{4}{*}{$-\cdots$} & Irant & - & 192? & 25 & 53 \\
\hline & Tlirkery &. & $100 ?$ & $1 \%$ & 50 \\
\hline & Viernam & . & 1998 & 60 & 20 \\
\hline & India & - & $: 098$ & (i) 0 & 120 \\
\hline \multirow[t]{4}{*}{ Hyundai } & Fyypt & 1993 & :2y)x & 200 & 50 \\
\hline & Malaysia & $1(y 93$ & $(40) 8$ & $\vdots(01)$ & 20 \\
\hline & lndoncsia & 1994 & 1998 & $-\ldots$ & 50 \\
\hline & Pakistan & 1995 & $\cdot$ & 30 & 30 \\
\hline $\mathrm{Kia}$ & Indonesia & - & 1498 & 30 & So \\
\hline
\end{tabular}

Source: Park and Kirrı, 199? 41.

\section{CONCLUSION}

South Korea's automobile industry exemplifies an interesting combination of core and semi-peripheral characteristics. With strong government support and protectionist stratcyies employed in the early stage of development, South Korea successfully transtormed its automobile industry from simple knockdown assembly to a global industry in less than three decades. By the mid-1980s, South Korca was exporting finished automobiles to core markets, albeit competing primarily in the low price rather than high quality niche.

Extensive capizal investments and technological alliances were made with Japanese 
and U.S. automobile producers. In Latin America, the Big 'Ihree automobile makers trom the United Srates have played an overwhelmingly central role in providing capital and technology. However, in South Korea it has been the Japanesc automobile producers, such as Mitsubishi, Mazda, Nissan, and Honda, who have made extensive capital investments and technology transfers. Geographical proximity, a superior after-service? systern, and cultural aftinity appear to have made Japanese automobile producers popular among South Korea's leading automobile producers.

Domestic corporations control the South Korean nerwork of automobile parts production with exclusive subcontracting relations. This makes the South Korean case quite discinct from the United States, while similar to the Japanese. Subcontractors in South Korea ofren have exclusive ties with assemblers, and demonstrate a high level of dependence to the chacbul-affiliated automobile producers.

Automobile production has become increasingly globalized in che 1990s, in particular investing in semi-periphery countries to take advantage of cheaper babor and other producrion costs as well as to gain access to emerging markets. Data in recent yciars demonstrate a growing rend in global diversification which contrasts to the first threc decades of auromobile production in South Korca.

This paper challenges the assumptions of the PDCC analysis in two imporcant ways. First, the South Korean case suggests that a semi-periphery can survive in the core nation-dominated work automobile market by finding its niche in cheaper cars and in cmerging markets, where automobile 'INCs from cors nations have "graduated" from with technological upgrading. Some of the favorable international market conditions may be difficult to replicate in other semi-peripheral nations. Nonetheless, the South Korean case shows that an industry such as automobile production is nor the exclusive dumain of core nations.

Secondly, the South Korean case proves that the domestic government's support is critical in the development of an automobile inchustry. The wealth and influence of the parent ihatbol. along with the government's supportive policies, have enabled South Korean automobile producers to dominate the domestic matket and ancouraged fftorts (1) develop indigenous technology and models rather than relying on TNCs.

Recent restructuring efforts in the South Korean automobile industry since the 16j)? Asian financial crisis will no doubr bring substantial changes to this inclustry. Kia Motors wias incorporated into Hyundai Motors due to the former's bankruptiy in the sumner of 1997. Thus, Hyundai constitured a 73.2 percent of the domestic market share in the first six montlss of 2000 . Ssangyong Motors and Samasung Motors have been incorporated into Dacwou Motors. Thete have also been major $\mathrm{M} \& \mathrm{~A}$ activities with foreign giant automobile TNCs. Renault, the French automobile proxlucer, rook over Samsung Motors, and Ford purchased Daewe Motors. Thus, the: number of Sxuch Korcan auromobile producers has gone from ninc to three in the wake of the finincial crisis. Discussion is still underway in some of these cases, exposing the great difficulties that arise in merging former competicors, especially with the absorption (or, more importantly, lack of there) workers. The newly restructured South Korein autornobile industry consisting 
of three gigantic automobile producers, two of which are affiliated with powertul thestont and one with a $\mathrm{INC}$, will no doube bring major changes to the global commodity chaisin of automobile production.

future research is needed to examine the impact of this new comperition system of automobile production on the domestic market and on the PI)CC in South Korea, especially in light of the growing globalization trend of conmodities. Although cutthroat domestic competition may decrease to a certain extent, the three automobile proctucers face a tough battle with the opening of South Korea's automobilc market to major auto 'I'NCs, as well as to the international platform.

\section{REFERENCES}

Abernathy, William, Kim M. Clark, and Alan M. Kanrow, 1993. Indinstmal Renatssante. Now York: Basic Books Inc. Publishers.

Applebaum, Richard P. and Gary Gereffi. 1994. "Power and Profits in the Apparcl Commodity"

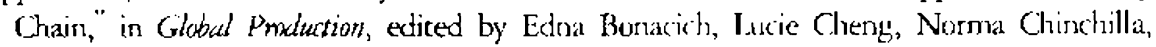
Nora Hamilton and Paul Ong. Philadelphia: Temple Lniversity: Press.

Bonacich, Edna, Lucie Cheng, Norma Chinchilla, Nora Hamileon and Paul Ong, eds. lery4. Glibal Prsklution. Philadelplua: 'Temple University Press.

Cho, Chul. 1\%)8. The Pan Supply Netuork and Ways for Impritumem. Seuul: Korea Inscitute for Industrial Economics and Trade.

DuBois, Frank I., Brian Toyne and Michael D. Oliff. 1993. "International Manufacturing Strategies of L.S. Multinationals: A Conceptual Framework Based on a Four-Industry Study." Jotmal of Intemational Business Sukdies, Second Quarter: 307-33.

Evans, Peter. 1994. "Predatory, Developmental. and Other Apparatuscs: A Comparative Political Economy Perspective on the Third World State," in Comparatite National D. relopment, cdited by A. Douglas Kincaid and Alcjandro Portes. Chapel Hill: The Lniversity of North Carolina Press.

Feenstra, Robert. 198)8. "Integration of Trade and Disintegration of Production in the Gilubal (i)untry." The fotsmat of Esonomic Perspetine 12 (4): 31-50.

Cecteffi, Gary. 19\%4. "The Organization of Buycr-Driven Global Commuxdity Chains: How the L.S. Retailers Shape Overseas Production Networks," in Comonodity Chains and Global Capitalism, edited by Gary Gereffi and Miguel Korzeniewicz. W'estport, Conn.: Greenwond Press.

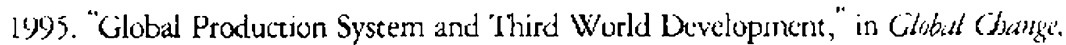
Reginuth Reyponute cdited by Barbara Stallings. New York: Cambridge Liniversity Press.

Gereffi, Gary and Miguel Korzeniewicz. 19x)o. "Commodity: Chains and Foorwear Exponts in the Scmipxeriphery," in Semiperipheral States in the World Fammm: edited by William (;. Martin. Westpurt, Conn.: Greenwoxd Press.

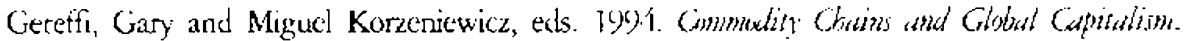
Westport, Coms: Greenwoxd Press.

Hill. Richard Child. 1989. "Comparing Transnational Production Sysrem: The Rutomobile Indusery in the LISA and Japan." Intmational Joumat of Lirban and Regitond Restarbs 13 (b): $162-80$. 
Hyundaj Moror. 1\%97. Globalization Strategies of Hyzhdai Motor (Press Release).

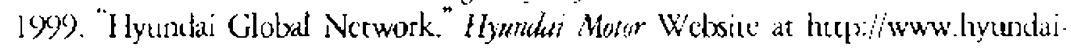
notor.conse.

Kim, Eun Mee. 1997. Big Business. Strong State: Collusion and Conflit in Soutb Koruan Iterviopment. $19(x)-(x)$. Albany, N.Y.: State Lniversity of New York Press.

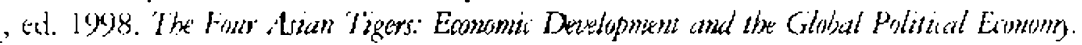
San Diego, Calif: Academic Press.

Kim, I.insu. 19)8. "Technology Policies and Straregies for Developung Countries: Lesstuns from the Korea Exporience." Technology Andysis and Siratgic Managentent 10 (3): $311-23$.

Kin, Hyung Kook and Su-H(xon Let. 1994. "Commodity Chains and the Korean Automobile Industry." In Commadity Chains and Glabat Capitalism, edied by Gary Gereti and Miguel

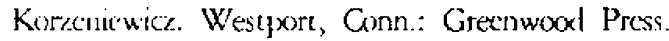

Kincaid, A. Ixouglas and Alejandro Portes, eds. 1994. Comparative National Dextopment. Chapel Hill: The University of North Carolina Press.

Korea Auro lindustries $C(x) p$ Association (KAICA), 2000). "Components Firms." KAlCA Website at herp:i/www kalicalor kr/kaka/moneyl htm/.

Kurea Automobile Manufactures Assoxiation (KAMA). 20)( "Autonobile Staristios." KAMLA W'bsite at herp:/inww.kamaor,ks/2/.

Kore $_{\text {ii }}$ Automobile Reseatch Insticute. 1997. "R \& D Investment in Automobile Industry of Major Autumobile Countries." Antomobile Industry Information 171. Seoul: Iyuikda Motor.

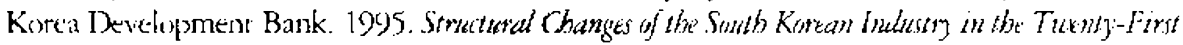
(kisur; and Outlozk. Sxroul: Korea Development Bank.

Korca Instirute for Industrial Economics and Trade (KIET). 19)7a. Industry in Soul Kowa: The Histom of Deneligment and the Vision for the Futwe. Seoul: Korea lostitute for industrial Liconomics and Track.

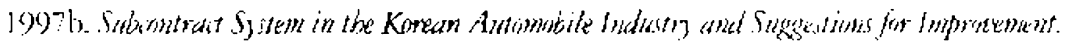
Seonl: Korea Institute for Industrial Fonnomics and Trade.

Koreil Institute of Industrial 'Technology, Evaluation and Plinning (ITEP). 1 (s)6. Demand

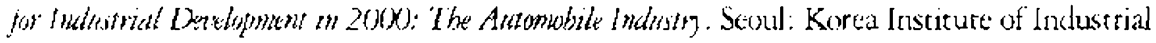
'Tothology, Evaluation and Planning.

Lee, Varlyoung and Jeffrey Cason. 1994. "Automobile Commodity Chains in the NICs: A Comparison of South Korea, Mexicu, and Brazil." In Commolity. (hains and Global Capitalim, adited by Gary Gereffi and Miguel Korzeniewicz. Westport, Conn.: Greenwood Press.

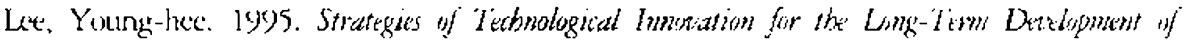
the dutmobili lmatny. Seoul: Science and Teclunology Policy lnscitute.

Matej Business News. Mukil Buiness News. April 28, 1999.

Ministry of Commerce, Industry, and Energy (MOCIE). 1947. HOCIE Websice ac hatp:ll www.mocit.go.kr/.

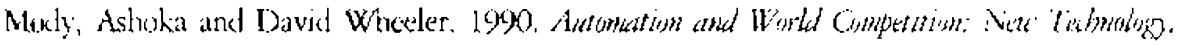
Indrotrial Lewation and Trate. Isondon: Macmillan.

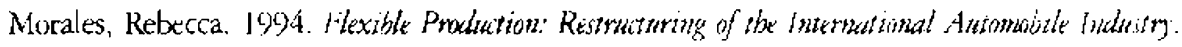
Cambridge: Polity Press.

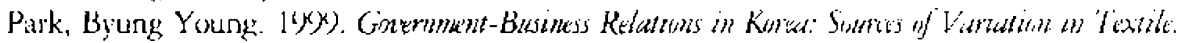

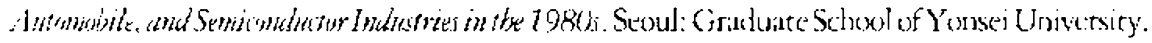

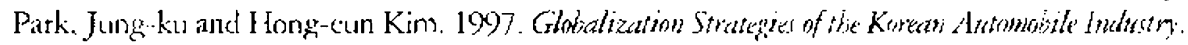
Sersul: Korea Institute for lndustrial Economics and Trate.

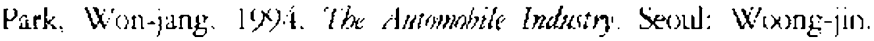


Rabach, Eileen and Eun Mee Kim. 1994. "Where is the Chain in Conmodity Chains: The

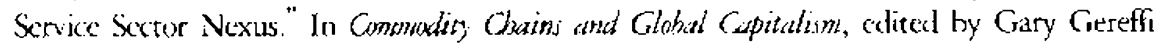
and Migucl Korzeniewicz. Westport, Conn: Greenwond Press.

Rhee, Jong-Chan. 19x)4. The State and Industry in Snath Korea. Now York: Routledge.

Sadler. David. 1999. "Internationalization and Specialization in the European Automotive Cornponents Sector." Regional Studies 23 (2).

Serul Sixial Economy Inscitute. 1998. The Strutwal Change and Challenges in Stuth Korad Autmmóile Industm. Seoul: Saenal.

Smitka, Michael. (x)1. Competitite Ties: Subontrating in the Jatpantie Automitit Industry. New York: Columbia University Press.

Stallings, Barbara. ed. 1995). Global Change, Regional Reshentie. New York: Cambridge University Press.

Time. "Let's Make a Deal." Tinu, January 25, 1999, pp.32-33.

. "Glubal Motors." Time, February 8, 199\%, 13.3? 


\section{APPENDIX I}

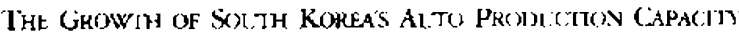
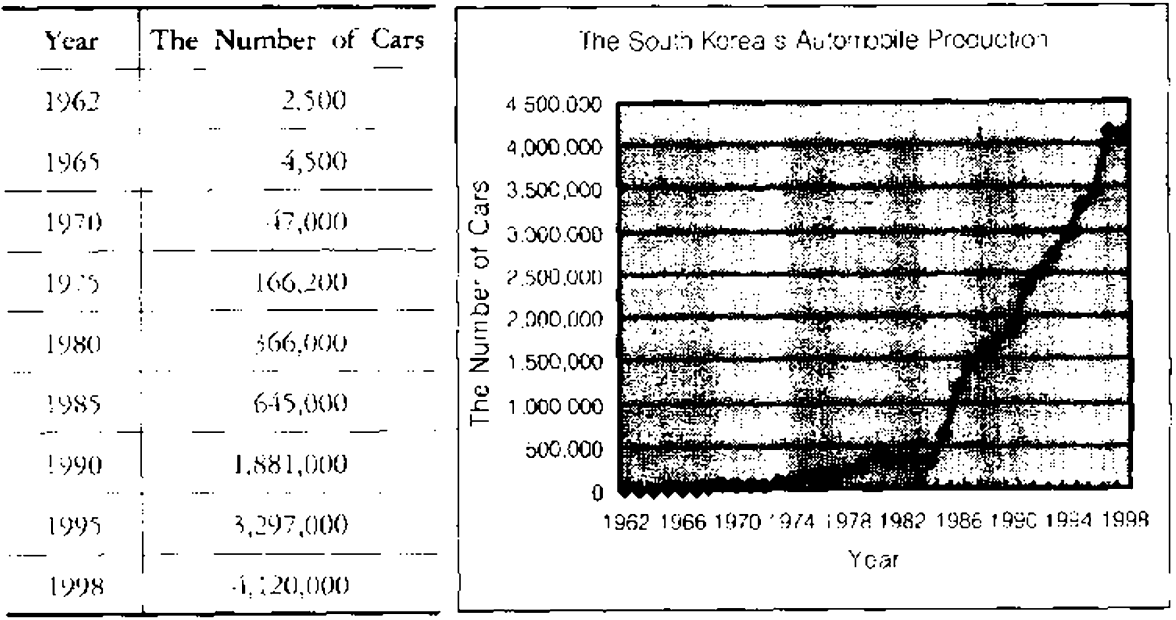

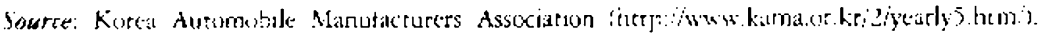

THE RANK OF SOLTH KOKEA IN THE WORSD MI JO MARKEI

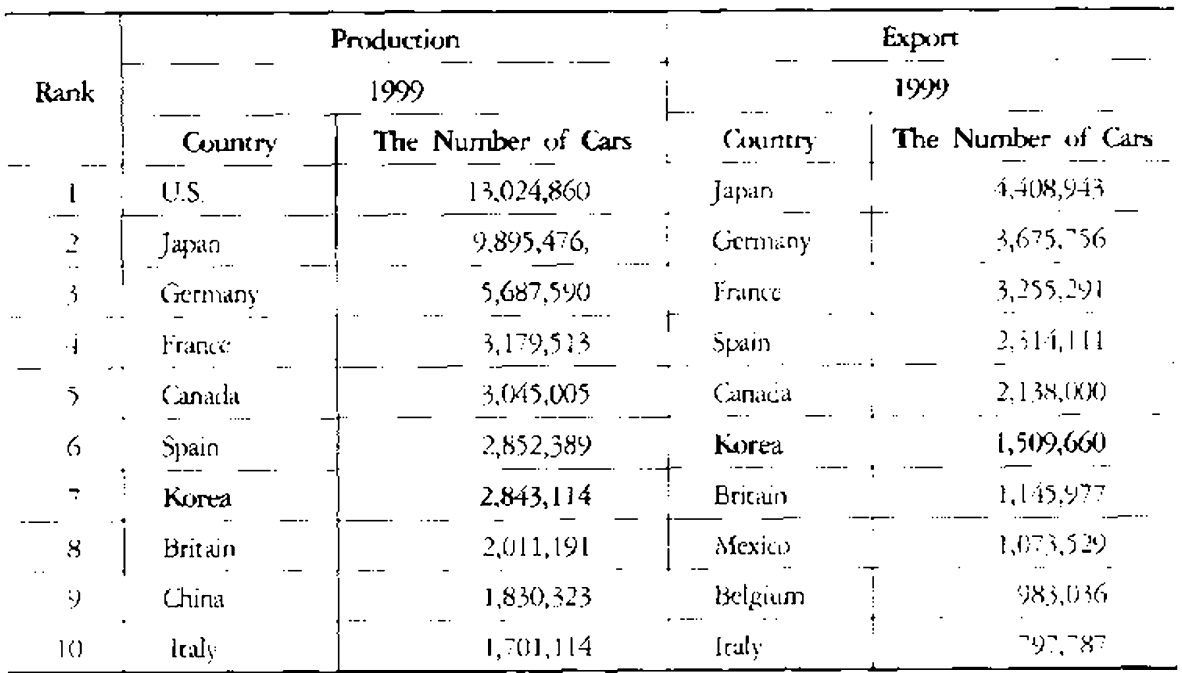

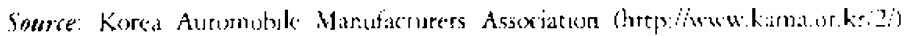




\section{APPENDIX 2}

\section{CHRONOLCXY OF SOLITH KORFAS ALTOMLOHIL INIB:STRY}

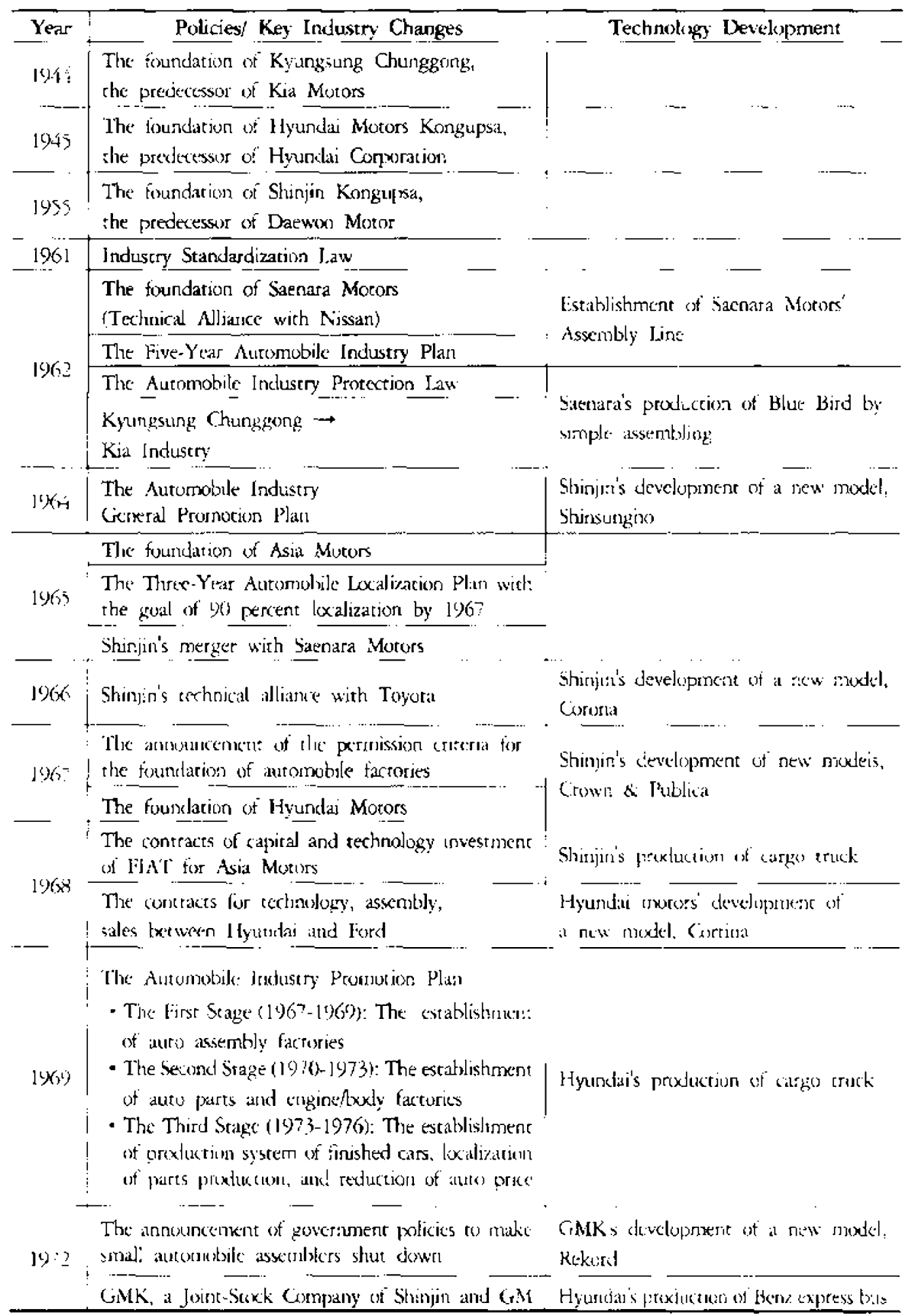




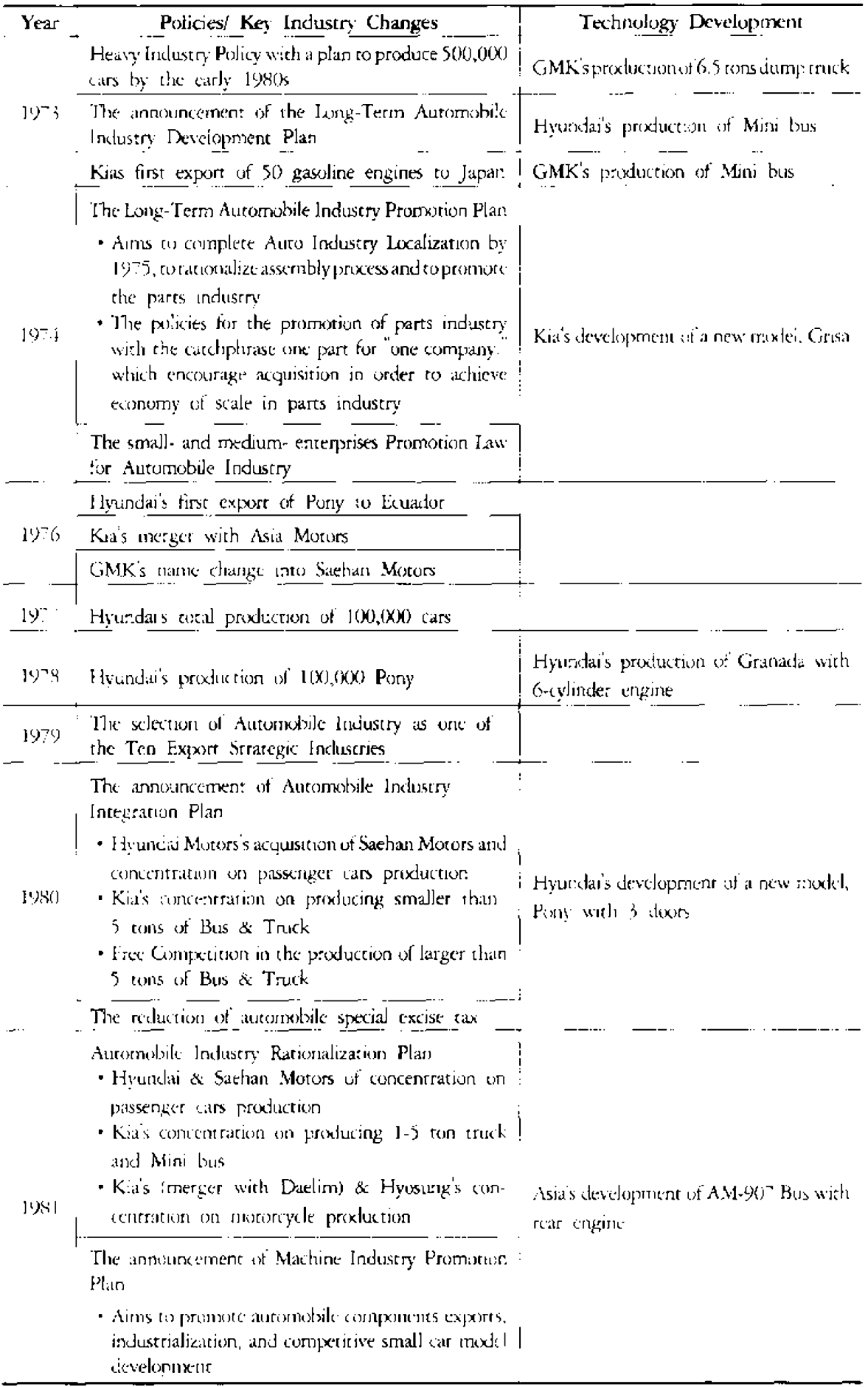




\begin{tabular}{|c|c|c|}
\hline Year & Policies/ Key Industry Changes & Texhnology Development \\
\hline 1983 & Saehan's tame change into Daewoo Motor & \\
\hline 1984 & $\begin{array}{l}\text { The gowernment approwil of Hyundai and Dacwex } \\
\text { Motur for Diescl Engine: Producen }\end{array}$ & \\
\hline 1085 & I nuflion cars owined by Korean & $\begin{array}{l}\text { Hyundais development of a nuw moxtel: } \\
\text { Excel with } 5 \text { dexn }\end{array}$ \\
\hline
\end{tabular}

$19 \mathrm{y}^{-}$Absogation of Automobile lndustry Rationalization

$198 \times$ Dungahts name change into Ssangyong Mocuss Korcai's proxluction of 1 million cars

Kias proxduction of Priste with 5 dixus

(9)e). Keduction of Automobili Import I'arits trom:

19y) 75 perrent to 20 petcent

-.....--

Reduction of Automoble Import Tariffs irsm

(अ) $1: 20$ percerit to 17 percent

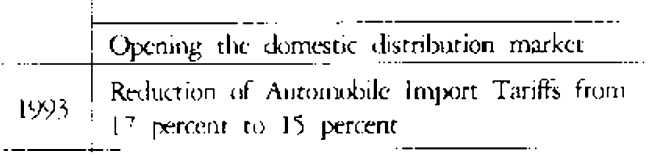

Recuction of Autumubile impors 'rarifis from 15 percent (1) 10 percent

$(9): 4$

Sanibung I teavy Induscries' rechnicial allyarke with Nissan

Sarnsunge Heary Industrices' laure hing of prodeccinge dump trucks

Reduction of Automobrile Imporsts Tariffs from 10 jercent tu 8 percent

1995 The foundarion of Samsung Motors

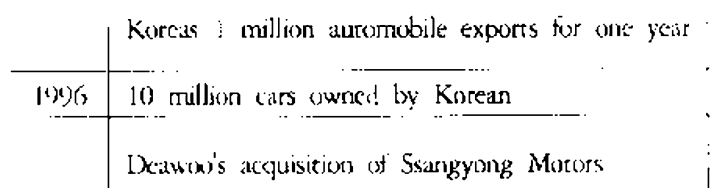

19) 8

Business swap berween Samsung Mutors and

Dakex(ro bilextronics ( $\lambda$ ).

Hỵındais arguisition of Kia's Motors
Hlyundai"s surcess in developing engrine and autonnatic transmission only with iadigenons rechrology for the first timx ia: Korta

Dacwex \& Asia Morers productuon of auxomobiles using I.PCi

Hyundai's developrent of a new model, Avante Touring (W/agon)

Kial's development of a new model, Sportage (Wagon)

Hyendai's proxtur rionote cargutructis w:th Q-engine

Hyntai's prodtiction or electro-mubi.'(4)

Samsung's devclopment of a aew modid, S.MS $20 / 525$

Hyundai's deseloprinern of ncew muxdels, II Smata \& Cirancklor XCi

Ssangy'my'sike welopmenti of a new menk:; Chairnan

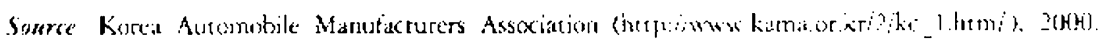

